rian fossils. The ranges of some species have been shown to be more extended than was formerly supposed, and for others new localities have been announced. The admirably prepared corals of Mr. James Thomson have further indicated, as was seen this evening, that nature-printing can be applied with success in the representation of fossils, and that the lantern can be used to make clear the minutiø of structure. The enumeration of problems in Scottish geology at the opening of the session was a well-tined reminder of what remains yet to be done. It is from no disregard of Mr. Page's advice that none of the difficulties he spoke of have been attacked; it only shows that there is a very wide field to go over before the materials for the higher generalisations, such as he alluded to, can be amassed. In conclusion, the President expressed his conviction that the labours of members during the summer would render next winter's session at least as fruitful of instruction as that which had now drawn to a close.

The Society then adjourned till the first Thursday in October.-J.A.

\title{
COREESPONDDINCE.
}

\section{THE DRIFT DEPOSITS OF THE EASTERN COUNTIES.}

\section{To the Editor of the GeoLogioal Magazinis.}

Dear Sir.-The communications from Mr. Hull and Mr. Searles Wood, junr., in the April number of the Magazine, called forth by my remarks on the relative ages of the Boulder-clays of the Eastern Counties, seem to invite a fẹw further observations from me. I wish, in the first place, to state that the object of my paper in the March number of the Magazine was rather to show that an order of sequence of the coast and high-level clays, fitting in with Mr. Dawkins' views of the Thames valiley deposits, was as probable as that supported by Mr. Wood, than that the evidence was absolutely conclusive as to the order of succession I suggested.

The individual members of the Glacial series contain scarcely any distinctive characters based on organic remains, and the constantly recurring local variations of their mineral character seems to render it almost hopeless to attempt any general classification on mere lithological evidence. This makes me view with less confidence than Mr. Wood the means of identification by which it is attempted to connect, in distant localities, the various subordinate members of the Drift series. With reference to the superposition of the Boulderclay of High Suffolk on that of the Norfolk coast; in the absence of an unbroken section, there seems to be scarcely sufficient available proof either that the green clay referred to by Mr. Wood is the equivalent of the Cromer Boulder-clay, or of the red loam south of Norwich; or, again, that there is an unquestionable identification between this red loam and the red sand which underlies the beds in the lower part of Dunwich cliffs, assumed by Mr. Wood to be the 
equivalents of his Middle drift. Moreover, this Middle drift is nothing but a mass of sand and gravel of constantly varying character, and having by itself no distinctive aspect.

I wish to explain that in referring to the general uniform altitude of the bed I termed "high-level Boulder-olay" (Mr. Wood's Upper drift), I did not suppose that this was any distinctive test of its age, as the original irregular basement line upon which it was deposited would to a certain extent determine its altitude; indeed, there are, I believe, several isolated patches in the neighbourhood of Tunstall, Chillesford, etc., at a mach lower level than the general mass forming the higher ground of Suffolk; but whilst a deposit having a great range of altitude may extend down to any point towards the sealevel, a uniform limitation of height (which is, I believe, the case with most of the Boulder-clays on the coast-line) may result from having been deposited by an agency that never attained beyond a certain level, and may therefore, in one sense, be taken as a distinctive test of age.

The clay which extends so widely over High Suffolk to an altitude of from two hundred to three hundred feet above the sea, never attains anything like this height in any coast section, and as you descend from the flat table-land it appears to be abruptly cut off by the general denudation-contour of the country.

The general level of the Chalk-surface in Suffolk is from eighty to one hundred feet above the sea, and on Mr. Wood's elassification his Lower drift accurring on the coast, wonld have formed with the Chalk a tolerably level basement line for the future superposition of his Middle and Upper drifts. How is it, then, that the clay on the high ground of Suffolk, which is se uniform in level and mass for many miles inland, disappears (or, on Mr. Wood's view, becomes attenuated) as the lower ground is reaehed? I believe it is only to be accounted for by the denudation of the clay on the higher level previous to the deposition, as a sort of fringing terrace, of that on the coast, which throughout the whole circuit of the country never, on the coast, attains the height of the inland drifts. If it is a mere extension, coastwise, of the drifts occurring at higher levels, the lower level of the base at the coast on which it was deposited would account for it ; but the coast Boulder-clay and drifts frequently occur where the higher ground, as you recede from the sea, is driftless. If this const-clay is as Mr. Wood supposes, a more ancient deposit than the higher drifts occurring inland, it seems difficult to aceount for the higher drifts which were deposited within a fow miles inland on the Chalk, not being also superimposed on the coast-drifts-the surface of which would have formed a foundation of about the same height as the inland Chalk.

Again, if it is assumed that the high-level Boulder-elay and subjacent gravel-beds (Mr. Wood's Upper and Middle drifts) form a portion of the cliffs on the Norfolk coast, descending towards the coast on a sloping base line, why should they become so attenuated in mass as in no instance to attain, with Mr. Wood's Lower drift, a collective thickness greater than that without the so-called Lower 
drift on the higher ground? as the attenuation of its mass would be likely to take place where the fundamental base was highest.

The following section (for which I am indebted to $\mathrm{Mr}$. Rose, of Great Yarmouth) of Corton cliff, between Yarmouth and Lowestoft, is one of the cases cited by Mr. Wood as an example of the supposed occurrence of his "Upper" and "Middle drifts," superimposed on his "Lower drifts."

The cliff is from thirty to fifty feet high, and consists of the following beds :-

a. Vegetable soil.

b. Warp of Mr. Trimmer, and "Upper drift" of Mr. Rose.

c. Boulder-clay, three to nine, or twelve feet thick. Boulders abundant, and varying from a few pounds to several tons in weight. Color of the clay various, occuring in extensive patches of blue, drab, and yellow.

d. Sand having in places false stratification, with shingle at its lowest portion fifteen to twenty feet thick.

e. Loamy clay, uniform in colour. Erratics small and scarce.

The bed $c$ is, I presume, that which Mr. Wood would correlate with his Upper, and $a$ with his Middle drift. From what I have seen of the cliffs south of Cromer, I must demur to the opinion that there is anything like a uniform succession of the beds for any distance along this coast. As a general rule, tough Boulder-clays occur towards the base of the cliffs, and sand, gravel, and silty beds, more or less contorted in its upper parts; but beyond this there is nothing like uniformity, and various sections could be described that it would be impossible to trace any kind of resemblance in, to that given above. Sand, gravel, Boulder-clay, and silt-beds interlace in endless variety, and I must take exception to an occasional resemblance in the order of superposition of the clays and sands along this coast, being adduced in support of their being the equivalents of the Boulder-clay and its underlying gravel bed, covering the higher ground of Suffolk.

The very variety of these coast-beds seem to distinguish them from the clay of High Suffolk: the high-level clay is generally uniform in color, and the materials smaller, and more even in size than in that of the coast, and it is seldom interstratified with sand beds. I have not seen the Corton Cliff section, but from Mr. Rose's description, I should judge that the series of beds there superimposed bears Iittle resemblance to the High-Suffolk drifts.

Mr. Hull suggests a relationship between the order of sequence laid down by Mr. Wood for the Eastern Counties, and the drift series in the neighbourhood of Manchester, expressing a hope that the drift question may be simplified by Mr. Wood's classification being found applicable to both sides of the Island. I fear the test of facts will scarcely support so simple a classification as the subdivision of the whole Glacial series into upper and lower Boulderclays, separated by a mass of sands and gravels. Such a uniformity over so great an area would be highly improbable, and scarcely consistent with the lithological changes observable within much smaller areas in the other Tertiary strata; furthermore, it seems to reduce the whole Drift era into one uniform progressive accumula- 
tion, and to ignore those complications of arrangement which might result from repeated periods of submergence, and the fresh distribution and reformation of the materials composing the earlier deposits. There are two obvious difficulties in the way of working out a uniform sequence on lithological evidence. 1st. The constantly varying character of each individual bed, clays and sands passing into each other, through gradations of clayey sand and sandy clay, which, unless you have an absolute continuity of section, renders certain identification impossible. 2nd. That after the coast line is left, the various levels at which the same bed may occur (following an irregular basement line, as pointed out by $\mathbf{M r}$. Hull, in his paper on the Manchester drifts), complicates the difficulty, rendering it impossible to pronounce with certainty to which division an isolated mass may belong. •

The following particulars of a few drift sections with their range of altitude above the sea, will illustrate the extreme difficulty of identifying the individual sub-divisions in distant localities-

Strethill, near Ironbridge, Severn Valley.-From 100 to 310 feet above sea; 210 feet thick. A stratified hill of drift, consisting of 70 feet of sand and gravel at its base, 70 feet of Boulder-clay, and capped by a further bed of sand and gravel 70 feet thick.

Buildwas, near Ironbridge, Severn Valley.-From 100 to 270 feet above sea, and a range of altitude of 170 feet. Within about a mile of Strethill, on the opposite side of the Severn Valley. Sands and gravels lying against the sloping side of the valley. No distinct bed of Boulder-clay.

Bridgnorth. - St. James' Gravel Pit, Severn Valley.-Eight miles below Strethill. 70 to 250 feet above sea level, and range of altitude of 180 feet. Terraces of gravel and shingle, with no distinct Boulder-clay. At Quat, two miles lower down the valley, the drift is almost wholly made up of the detritus of Bunter Sandstone, and in the cuttings of the Severn Valley Railway, at the same level on the west side of the valley, the drifts consist of loamy gravel of constantly varying character.

Ryden Hill, Benthall, Shropshire.-From 530 to 600 feet above the sea ; range of altitude and thickness 70 feet. An isolated knoll of clean sand and fine gravel.

Gravel-hole, Willey Park, near Broseley.-350 to 400 feet above sea; range of altitude, 50 feet, sand and gravel.

Burton, near Much Wenloch.- 750 to 800 feet above sea; range of altitude about 50 feet. Loamy sand and gravel, with transported boulders, but no tenacious Boulder-clay.

Middletown Raihway Station, Montgomeryshire.-Cutting west of station, 310 to 530 feet above sea; thickness $12 Q$ feet, consisting of 65 feet of tough clay, overlain by 45 feet of gravel and pebble beds, intermixed with clay and boulders.

Crowfild, near Coddenham, Suffolk.-From 100 to 200 feet above sea, thickness 100 feet, consisting of about 45 feet of sand and gravels, resting on the Chalk; overlain by $\bar{\delta} \delta$ feet of tough Boulder-clay.

Moel Tryfan, Carnarvonshire.-Alexandra Slate Quarries.-1270 to 1320 feet above sea, range of altitude 50 feet, consisting of from 20 to 30 feet of clean sand and gravel beds, containing shells, overlain by from 6 to 15 feet of Boulder-clay, containing transported stones or boulders. some of large size.

Moel Tryfan, Carnarvonshire (foot of the hill).-From 500 to 600 feet above sealevel, range of altitude about 150 feet. Boulder-clay skirting the base of the bill, of similar character to that near its summit.

This list of examples might be extended ad ixfinitum, but will suffice to show the extreme difficulty of distinguishing on any certain basis, and identifying in distant localities on mere lithological character, the individual subdivisions of the Drift series. If compared with the sections, enumerated by Mr. Hull in his 
memoir on the drift deposits of the neighbourhood of Manchester, it will be seen that the correlation of the individual subdivisions is utterly hopeless. If, for example, the Strethill Severn Valley Section, where there is the unusual consecutive thickness of 210 feet, is compared with the full series given by Mr. Hull in the neighbourhood of Manchester, it will be found that there is no possible correspondence in lithological subdivisions. At Strethill there is but one Boulder-clay separating two masses of gravel, and in the Manchester district one sand and gravel bed intervening between an upper and lower Boulder-clay. Both series seem to have about the same range with reference to sea level, but to bring them into possible correspondence as to lithological subdivision, it must be assumed, not only that one of the Manchester Boulderclays is absent in the Severn Valley, but that one of the Severn Valley gravel beds is missing at Manchester. These changes will, however, be more easily explained by recognising the extreme local character of the great mass of the materials making up the drifts, and consequently the continual variation of their lithological condition, depending on the sources of materials and the local circumstances of surface contour under which each was deposited.

The extreme uniformity in the mineral character of the higher Boulder-clay of the Eastern Counties is remarkable, and contrasts with the varying composition of the drifts in other parts of the kingdom. The fact that there is nowhere to be found, on the immediate coast, such a thickness of drift as frequently occurs on the higher ground, seems to render it probable that the comparatively uniform terrace of clay, fringing the coast, was deposited during a limited submergence, when the coast outline differed little from what it is at present. If the coast clays and drifts are merely a seaward prolongation of those occurring at much higher levels inland, it seems difficult to account for its never capping the coast cliffs of the older formations that exceed 200 feet in height, and if it is the same drift on the coast that rises within a few miles (as for example on Moel Tryfan) to more than 1000 feet, it would be expected to rise over the older formations on the coast cliff line, and if the coast clay is older than the drift on the higher ground, how is it that the higher is not superimposed on the lower, forming a collective mass somewhat approaching the height of the inland drifts superimposed on the older formations? Another point to be noticed is, that the fringing terrace of clay is often present (as for example on the Yorkshire Coast) along the coast where the adjacent higher ground is driftless. In connection with this point may be noticed the occurrence of erratic boulders at Pagham and along the coast, west of Bognor, Sussex, the ground a little above the coast line being entirely without drift; indeed, nearly the whole coast circuit affords evidence of this limited submergence. The driftless area of Devonshire is on the south coast fringed with gravels, which seldom reach more than 150 feet above the sea, and on the north the great deposit of clay and an underlying gravel bed, near Fremington and Barnstaple, betokens a similar limited amount of submergence. 
The general absence of drift at a high level on the coast-as, for example, on the top of high coast cliffs-can only be accounted for by its having been denuded previously to the deposition of the fringing terrace of low level clay and drift, and of this there seems good evidence, as the contour of much of the higher drift partakes of the general denudation contour of the older rocks, implying a deposition previous to the excavation of some important river-valleys, and to the existence of the present surface contour.

Benthall Hali, Broseley,

Georgu Maw. April $12 t h, 1867$.

Note.-Since the above was written Mr. Fisher's article "on the Ages of the Trail and Warp" has appeared in the Magazine. As I have had but little opportunity of examining the deposit designated by Mr. Fisher as "Trail," I must defer to his opinion that it is identical with what Mr. Dawkins considered to be a Glacial deposit overlying the Brick-earths of the Thames valley; at the same time if it is a subaërial deposit, arranged by the action of land-ice, it does not seem improbable that it may be the equivalent in time of the coast Boulder-clay.

If I rightly understood Mr. Dawkins' observations in the discussion on his paper, he seemed rather to consider the supposed Glacial deposits of the Thames valley as a submarine than a subaërial formation. Under any view, the facts brought forward by Mr. Fisher seem consistent with a long interval between the deposition of the Boulder-clay on the higher ground of the east of England, and that of the supposed Glacial beds of the Thames valley. As the highlevel Boulder-clay is intersected by the present valley system, whilst Mr. Fisher's "Trail" follows its denudation contour, I believe there is evidence that the Till of the Norfolk coast was also deposited after the Boulder-clay of the high ground had been considerably denuded.

The deposit in the valley of the Yare, described as "a Third Boulder-clay," in Mr. Harmer's paper, just published in No. 90 of the Quarterly Journal, appears to occupy a similar position to that which I believe the coast clay of Cromer, Mundsley, etc., bears in relation to the Chalk, Crag, and High-level Boulder-clay, and may merely be an inland extension of the beds on the coast, deposited after the land surface received its present denudation contour.

Similar beds of Brick-earth to that numbered 5 in Mr. Harmer's section, occur interstratified with the bed of gravel (Mr. Wood's Middle Drift), underlying the Boulder-clay of High Suffolk, and its identification with the coast clay seems to me scarcely supported by sufficient proof.-G.M.

ON THE PARALLELISM OF THE DRIFT DEPOSITS IN LANCASHIRE AND NORFOLK.

To the Editor of the Grological Magazing.

SrR,-Mr. Hull has very faithfully drawn, although in somewhat rough outlines, a parallel between the Drift deposits in Lancashire 